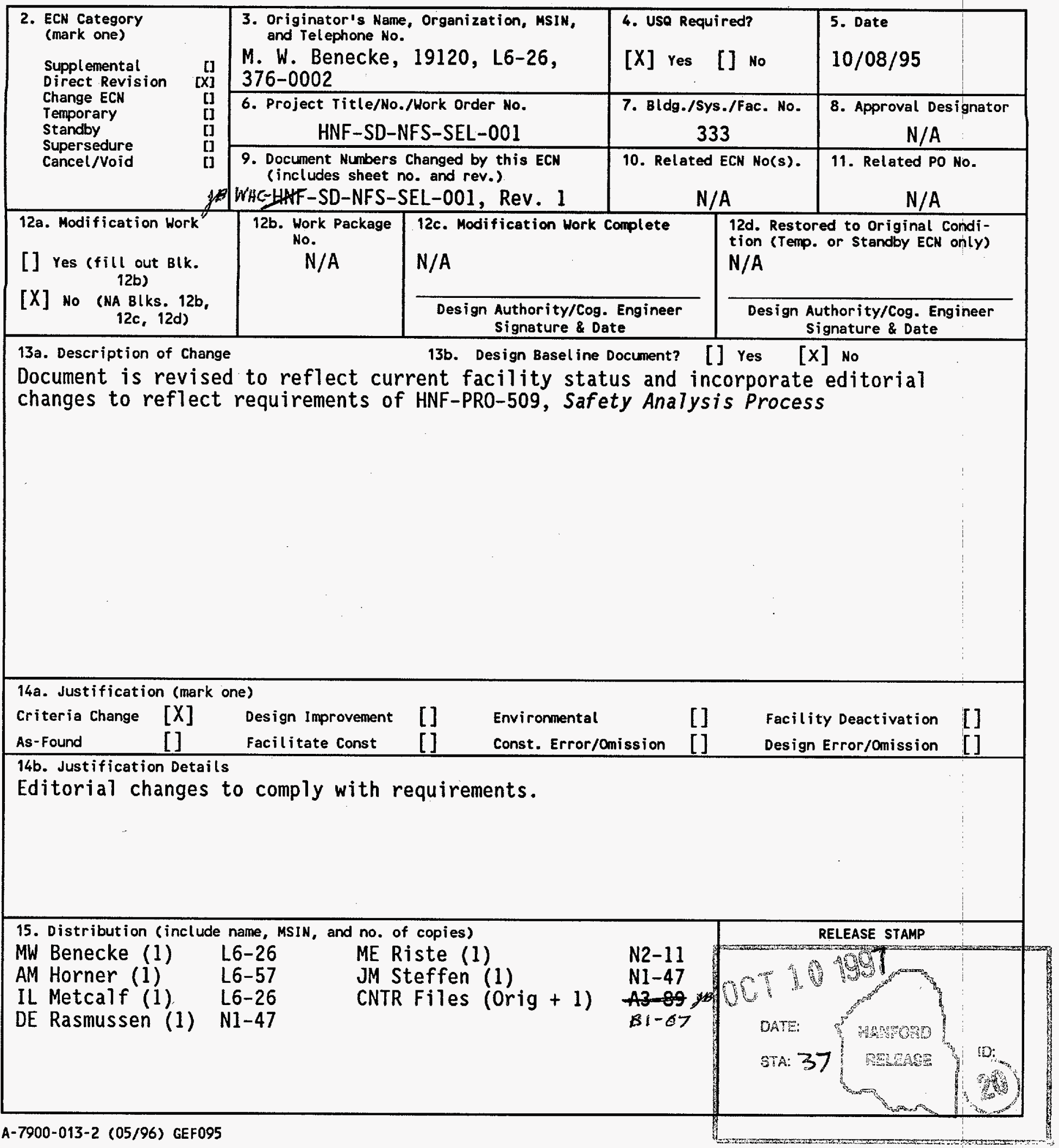




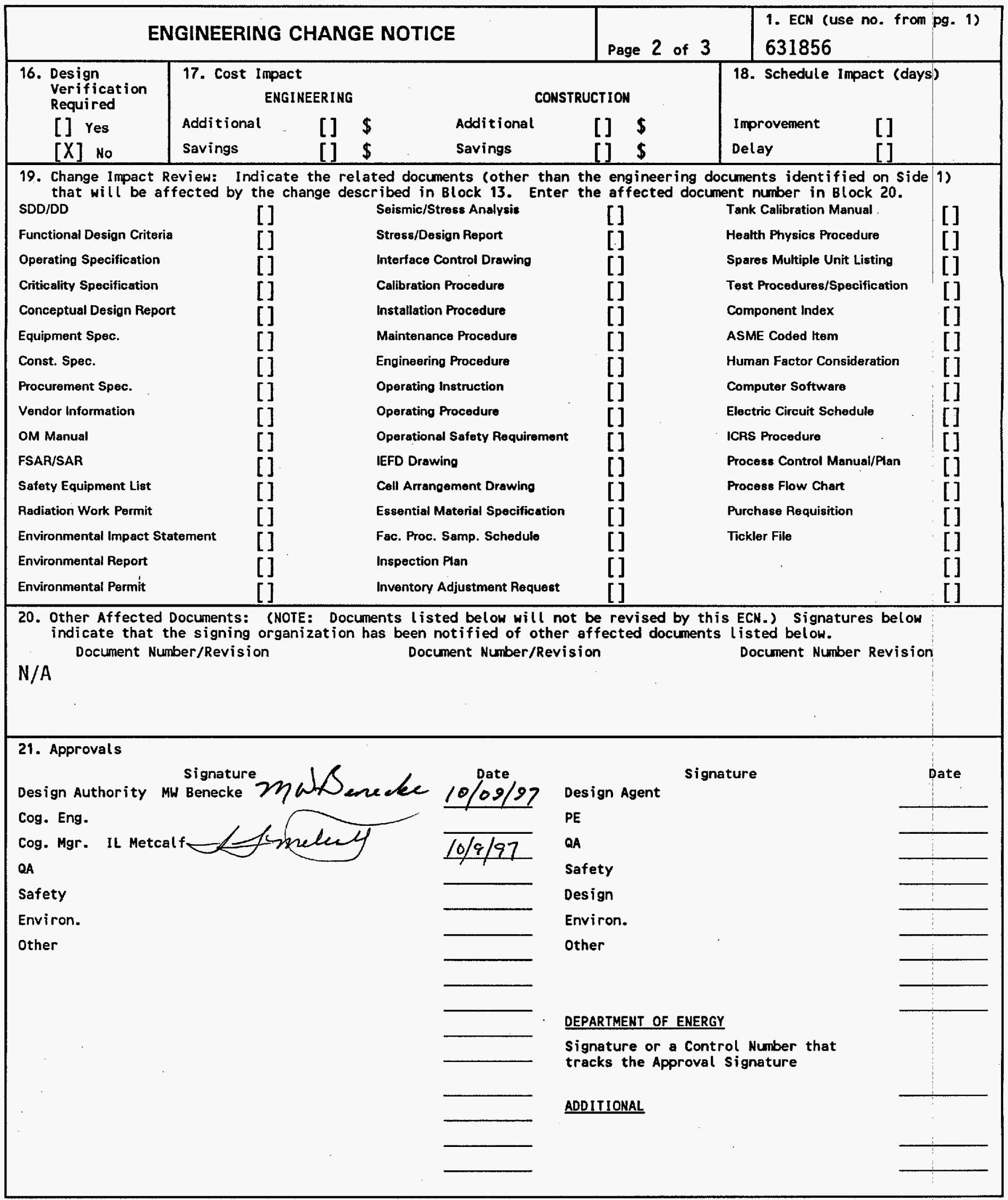




\begin{tabular}{|c|c|c|}
\hline 1. Identification Number: FSS-123 & USO SCREENING & Page 1 of \\
\hline
\end{tabular}

2. Title: HNF-SD-NFS-SEL-001, Rev. 2, Safety Classification of Systems - 300 Area N Reactor Fuel Supply Facilities

INSTRUCTIONS: Respond to each question and provide justification for each response. A restatement of the question does not constitute a satisfactory justification or basis. An adequate justification provides sufficient explanation such that an independent reviewer could reach the same conclusion based on the information provided [DOE 5480.21, 10.e.1].

QUESTIONS

1. Does the proposed change or occurrence represent a change to the facility or procedures as described in the Authorization Basis?
[] $N / A$
$[\mathrm{X}]$ No
[] Yes/Maybe

BASIS: Revision of WHC-SD-NFS-SEL-001, Rev. 1, which documents the safety classification of Fuel Supply Shutdown facility items, will not change any documents described in the A.B. This revision continues to refiect the designation of FSS facility items as described in the ISB but changes to comply with the current HNFPRO-516 designation of SSC.

2. Does the proposed change or occurrence represent conditions that have not been analyzed in the Authorization Basis? [] N/A [X] No [] Yes/Maybe

BASIS: Revision of WHC-SD-NFS-SEL-001, Rev. 1, is an administrative revision that does not change any aspect of the A.B. or description of FSS facility sytems or equipment.

3. Does the proposed change represent a test or experiment NOT described in the Authorization Basis that may affect the safe operation of the facility?

$[X]$ N/A [] No [] Yes/Maybe

BASIS: Revision of WHC-SD-NFS-SEL-001, Rev. 1, is neither a test nor an experiment.

4. Does the proposed change or occurrence represent a change to the Technical Safety Requirements or a reduction in the margin of safety defined in the Technical Safety Requirements?
[] $\mathrm{N} / \mathrm{A}$
[X] No
[] Yes/Maybe

BASIS: Revision of WHC-SD-NFS-SEL-001, Rev. 1, does not represent a change to the TSRs or reduce the margin of safety as defined in the TSRs because this revision merely documents the safety status of equipment as defined in the ISB.

USQE \#1 MW Benecke

USQE \#2 JA Remaize

(Print Name)

(Print Name)
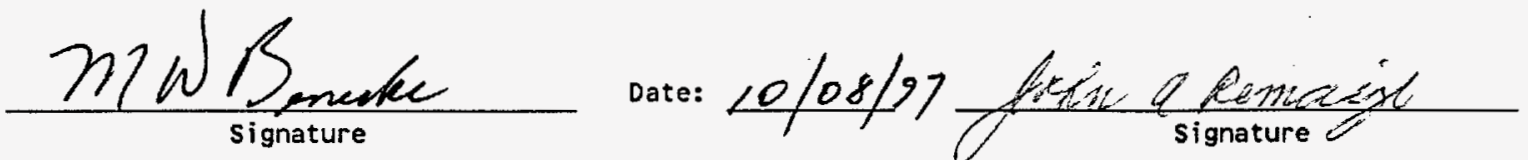

Date: $10,0.92$

If there is a YES/MAYBE response to questions 1, 2, 3, or 4, then a USQ Evaluation must be completed.

The following guidance should be considered when completing this screening. This guidance should not be considered allinclusive; additional factors may need to be considered depending on the nature of the proposed change.

Does the proposed change:

1) Modify, add, or delete a safety class function of a structure, system or component stated in the authorization basis?

2) Alter the design of a structure, system or component as described in the authorization basis?

3) Modify, add, or delete the description of operation, operating environment, or analyses of any system or component described in the authorization basis?

4) Modify, add, delete or conflict with any of the design bases stated in the authorization basis?

5) Conflict with the principle or general design criteria stated in the authorization basis?

6) Modify, add, or delete any plant design features described in the authorization basis?

7) Modify, add, or delete a flow diagram or facility drawing provided in the authorization basis?

8) Create the potential for new system or component interactions (e.g., seismic, electrical breaker coordination)? 


\section{SAFETY CLASSIFICATION OF SYSTEMS 300 AREA N REACTOR FUEL SUPPLY FACILITIES}

M. W. Benecke

B\&W Hanford Company

PO Box 1200, Richland, WA 99352-1200

U.S. Department of Energy Contract DE-AC06-87Rt10930- $96 \mathrm{RL} 13200$

$\begin{array}{lll}\text { EDT/ECN: } & \text { ECN } 631856 & \text { UC: } 2050 \\ \text { Org Code: } & 19120 & \text { Charge Code: K35F2 } \\ \text { B\&R Code: } & \text { DP0405501 } & \text { Total Pages: } Z_{7 z} E\end{array}$

Key Words: Safety Systems, Safety Equipment List, Safety Significant (SS), Safety Class (SC), Fuel Supply Shutdown

Abstract: Classification of the Fuel Supply Shutdown (FSS) safety systems, equipment, and components is presented.

TRADEMARK DISCLAIMER. Reference herein to any specific commercial product, process, or service by trade name, trademark, manufacturer, or otherwise, does not necessarily constitute or imply its endorsement, recommendation, or favoring by the United States Government or any agency thereof or its contractors or subcontractors.

Printed in the United States of America. To obtain copies of this document, contact: WHC/BCS Document Control Services, P.O. Box 1970, Mailstop H6-08, Richland WA 99352, Phone (509) 372-2420; Fax (509) 376-4989.
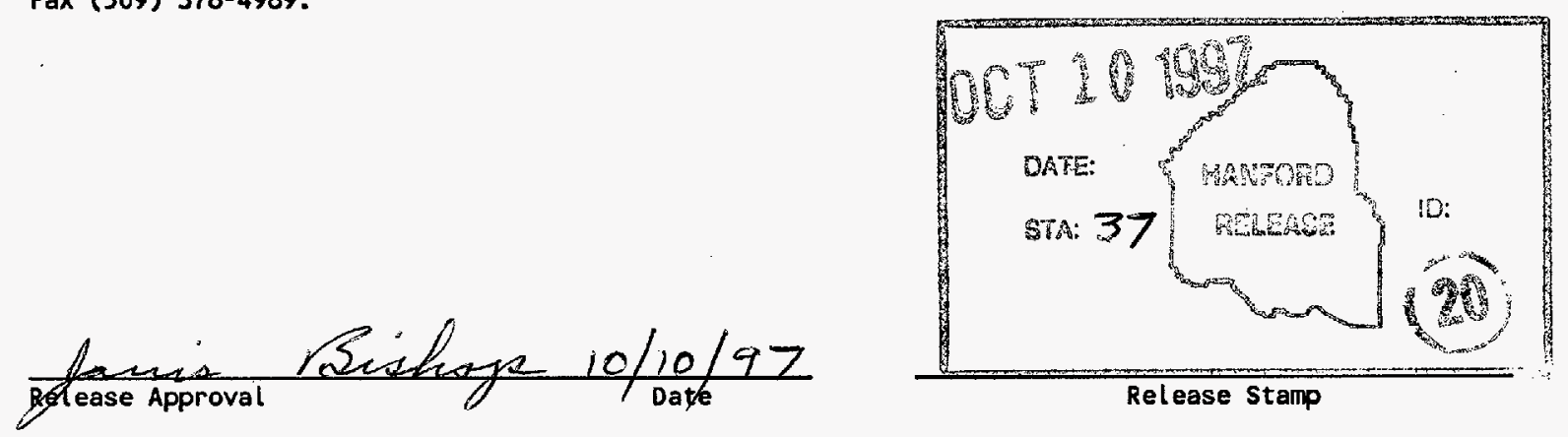
(2) Title

Safety $\mathrm{Classification} \mathrm{of} \mathrm{Systems} 300$ Area $\mathrm{N}$ Reactor Fuel Supply Facilities

CHANGE CONTROL RECORD

\begin{tabular}{|c|c|c|c|}
\hline \multirow{2}{*}{ Revision } & \multirow{2}{*}{ (4) Description of Change - Replace, Add, and Delete Pages } & \multicolumn{2}{|c|}{ Authorized for Release } \\
\hline & & (5) Cog. Engr. & (6) $\mathrm{Cog} . \mathrm{Mgr}$. \\
\hline 0 & (7) Initial release. & & \\
\hline 1 & $\begin{array}{l}\text { Complete revision to comply with } \\
\text { WHC-CM-4-46 }\end{array}$ & MW Benecke & IL Metcalf \\
\hline 2 RS & $\begin{array}{l}\text { Complete revision to reflect current status } \\
\text { and to incorporate editorial changes } \\
\text { consistent with HNF-PRO-509. }\end{array}$ & MW Benecke & $\begin{array}{l}\text { IL Metcalf } \\
\text { Sfondeley }\end{array}$ \\
\hline & & & \\
\hline & & & \\
\hline & & & \\
\hline & & & \\
\hline & & & \\
\hline & & & \\
\hline & & & \\
\hline & & & \\
\hline & & & \\
\hline & & & \\
\hline & & & \\
\hline & & & \\
\hline & & & \\
\hline & & & \\
\hline & & & \\
\hline & & & \\
\hline & & & \\
\hline & & & \\
\hline & & & \\
\hline & & & \\
\hline . & & & \\
\hline & & & \\
\hline & & & \\
\hline & & & \\
\hline & & & \\
\hline & . & & \\
\hline & & & \\
\hline & & & \\
\hline & & & \\
\hline
\end{tabular}


BABCOCK \& WILCOX HANFORD COMPANY

October 1997

For the U.S. Department of Energy Contract DE-AC-06-87RL10930 
This page intentionally left blank 


\section{CONTENTS}

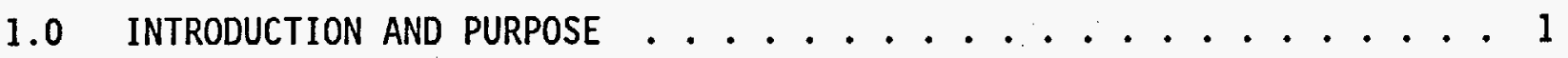

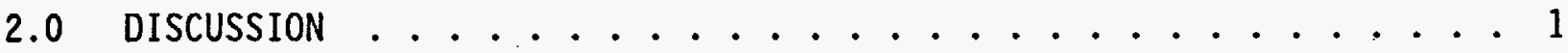

3.0 CLASSIFICAITON METHODOLOGY AND RESULTS ............ 2

4.0 SAFETY EQUIPMENT LISTS . . . . . . . . . . . . . . 3

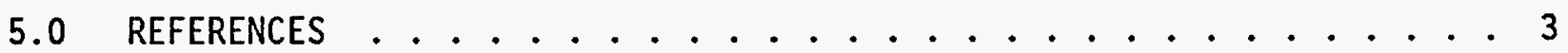


SAFETY CLASSIFICATION OF SYSTEMS

300 AREA N REACTOR FUEL SUPPLY FACILITIES

\subsection{INTRODUCTION AND PURPOSE}

HNF-PR0-509, Safety Analysis Process, (Reference 1) requires that nuclear facilities classify systems, components, and structures within the plant in a documented fashion. This document establishes the safety classifications for the 300 Area Fuel Supply Shutdown (FSS) facility items.

\subsection{DISCUSSION}

The FSS complex consists of 15 buildings, plus a utility trench, burial ground, storage tanks, and a mobile office.

At present, special nuclear material (SNM) is stored in five buildings $(3712,3716,303 \mathrm{~A}, 303 \mathrm{~B}$, and 303G). The total amount of SNM currently stored in these buildings is 1200 metric tons (MT). The stored SNM consists primarily of finished uranium fuel elements, partially finished fuel elements, and billets. This uranium material consists of $0.71 \%$ (natural), $0.95 \%$, and $1.25 \%{ }^{235} \mathrm{U}$ enrichments. In addition, $3.4 \mathrm{MT}$ of depleted and natural uranium oxide powder and sintered pellets and 0.47 MT of thorium oxide powder that require disposition are stored in the south portion of the 303K Building.

A hazard categorization (Reference 2) has been prepared for the facility in accordance with DOE-STD-1027-92 resulting in the assignment of Hazard Category 3 for FSS. Only those buildings that may store fuel materials (303A, $303 \mathrm{~B}, 303 \mathrm{E}, 303 \mathrm{G}, 3712$, and 3716) are designed Category 3 buildings. A11 others are designated radiological buildings except the 334, 334A, and M0052 Buildings.

Interim Operational Safety Requirements (Reference 3) have been prepared based on the Interim Safety Basis (ISB) (Reference 2).

It was concluded in the Interim Safety Basis (ISB) (Reference 4) that the risk associated with the current and planned operational mode of FSS (uranium storage, uranium repackaging and shipment, clean up, and transition activities, etc.) are within risk guidelines per HNF-PRO-514, Risk Guidelines (Reference 5). The dose and toxicological consequences for a range of credible fires, including a uranium storage building fire, have been analyzed using current accepted methods. The radiological and toxicological consequences for the maximum credible event are less than Guidelines Consequences that would require engineered safety features (Safety $\mathrm{Cl}$ ass or Safety Significant items) as shown in Table 1.6-1 of the ISB.

It is also concluded that because of the incredible probability for a nuclear criticality that a criticality alarm system (CAS) is not required as allowed by DOE Order 5480.24. Accordingly, the presently installed CAS has been shut down. 


\subsection{CLASSIFICATION METHODOLOGY AND RESULTS}

A review was conducted to determine if any FSS system, structure, or components would meet the safety class or safety significant criteria of HNFPR0-516, Safety Structures, Systems, and Components, (Reference 6).

Accidents with significant dose consequences have been analyzed. Since the maximum releases fall below the Safety Class and Safety Significant lower limits, no Safety Class or Safety Significant systems, structures, and components (SSC) are required. This safety class determination is based on the fire loading and associated uranium inventory of the 3712 Building being the worst-case fire possible. Refer to Table 1.6.1 of the ISB for safety class categories and associated criteria and calculated radiological consequences and toxicological concentrations for the maximum release.

Several systems and features do have the potential for safety significant classification. Upon evaluation, discussed below, it was concluded that there are no safety significant items at FSS.

1. Fuel storage buildings fire protection systems

Function: mitigate consequences of fire that could result in an offsite release of radiological materials.

However, the ISB states that a release from an unmitigated fire in a storage building would not exceed risk guidelines. Thus, these systems are not safety class SSC. Using the criteria of Table 1 in HNF-PRO-516, these systems should also not be safety significant SSC because they are not necessary to avoid an acute worker fatality or serious injury to a group of workers.

2. Criticality drains in fuel storage buildings

Function: provide a third contingency against accidental criticality involving fuel stored in these buildings.

Because these drains are not necessary to avoid the credible potential of accidental criticality (WHC-SD-NR-CSER-010, Rev. 1), they are neither safety class or safety significant SSC (per HNF-PRO-509).

\subsection{SAFETY EQUIPMENT LISTS}

\subsection{SAFETY CLASS}

None. 


\subsection{SAFETY SIGNIFICANT}

None.

\subsection{REFERENCES}

1. HNF-PR0-509, Safety Analysis Process, Project Hanford Management Contract, Richland, Washington.

2. HNF-SD-NR-HC-006, Rev. 0, Hazard Categorization for 300 Area $N$ Reactor Fuel Fabrication and Storage Facility, Fluor Daniel Northwest, Richland, Washington.

3. WHC-SD-NR-TSR-001, Rev. 0, Fuel Supply Shutdown Facility Interim operational Safety Requirements, Westinghouse Hanford Company, Richland, Washington.

4. WHC-SD-NR-ISB-001, Rev. 0-B, Interim Safety Basis for Fuel Supp7y Shutdown Facility, Westinghouse Hanford Company, Richland, Washington.

5. HNF-PR0-514, Risk Guidelines, Project Hanford Management Contract, Richland, Washington.

6. HNF-PR0-516, Safety Structures, Systems, and Components, Project Hanford Management Contract, Richland, Washington. 
HNF-SD-NFS-SEL-001

Rev. 2

This page intentionally left blank. 